\title{
Resolving the Human Remains Crisis in British Archaeology: Response to Sayer, Pitts, Pendragon, Elders, Lapinoja and Sutphin
}

\author{
Gabe Moshenska, Mike Parker Pearson ${ }^{\dagger}$ and Tim Schadla-Hall*
}

The papers in this forum highlight the passion and interest that human remains engender and the questions they raise about the past, the present, and the practice of archaeology. At the same time they reinforce our belief that the weak and often ambiguous legal frameworks surrounding archaeology are failing to meet the needs of all the parties concerned. This might reflect a lack of political interest in heritage, or the failure of heritage stakeholders to advocate effectively on its behalf. However, having begun to raise these issues and questions we are grateful to the respondents for taking the time to debate them with us, and to continue what has been and will no doubt remain a vital conversation.

Sayer's and Pitts' contributions help to contextualise the issues, offering insights based on long-term engagement in these and related debates, while highlighting the real threats that the law can present to the practice of archaeology. Sayer rightly notes the general lack of legal awareness within the archaeological community and the consequent problems, and highlights the Pagan reburial debate as an important factor in raising awareness of human remains issues within the discipline. He attempts to reconcile archaeology, science and religion as inter-

\footnotetext{
* UCL Institute of Archaeology

+ University of Sheffield
}

connected threads within European culture: while we would not dispute the important roles that all of these play in the construction of cultural and individual identities, it would be wrong to elide the historic and contemporary tensions between religious and rationalist world-views. The most valuable aspect of Sayer's response is the clarity with which he distinguishes the legal questions from the political/religious/cultural ones. We can only hope that the Ministry of Justice is as scrupulous.

Pitts takes a slightly less conciliatory tone, examining the wider debates around human remains in British archaeology and critiquing the reactionary ethno-nationalist strands in Pagan and Druidic discourse around the people of the past. In a robust defense of archaeology, Pitts argues that, while Pagans engaged in debates around human remains represent a small constituency, archaeologists and curators work on behalf of everyone (at least in theory). At the same time, Pitts attempts to reclaim for archaeology some of the most useful tools of science: uncertainty and humility. Human remains when properly studied offer only a blurred view into the lives of past peoples. We should be grateful for this view, and we should mistrust anyone who makes claims to certainties.

The ethno-nationalism in discussions of the dead that Pitts criticised is evident in Pendragon's response, which claims Pagan and Druidic beliefs as 'the indigenous beliefs 
of these pre-Christian isles'. The root of Pendragon's critique of archaeological treatment of human remains is clearly and simply put: 'people buried thousands of years ago should be treated in death with the same respect as those who passed over just last week'. He further argues that the people of the past were highly unlikely to have consented to themselves or their loved ones being exhumed for study after death. This powerful argument contrasts with Pendragon's attempts to highlight what he regards as 'double standards' in the treatment of the recent dead and the ancient dead. In doing so, he ignores such problematic and widely debated phenomena as von Hagen's plastinated Body Worlds displays, Damien Hirst's diamond skull For the Love of God, and the continuous and entirely legal destruction of relatively recent graves in municipal cemeteries. Pendragon presents several questions relating to these supposed double standards. For example:

Why is it, if you were to put a human skull atop of a staff, you would be viewed as a barbarian, put the same skull behind glass and you are viewed as a 'scientist'?

This is a false dichotomy - there are numerous contexts in which neither of these would be the case: either practice might fall within the remit of a curator or, conversely, a serial killer. A scientist is more likely to take a skull out of a case for a closer look at it; a barbarian is more likely to (re)bury the skull thereby mindlessly erasing the stories that it might tell.

Why are 'the cremation pits' at Stonehenge allowed to be disturbed whilst those at Salisbury Crematorium are protected under British law?

This patent falsehood demonstrates a total lack of understanding of human remains law. The central point of the initial paper was that the same laws apply to both.
It would be a shame to allow these disagreements to detract from the main message of Pendragon's response, which notes the general lack of animosity in debates between archaeologists and Druids, and emphasises a common concern for the decent and respectful treatment of the dead.

Elders offers a brief and sober analysis of the legal processes discussed in the initial article, noting a 'general confusion' on all sides. His outline of the process brings to mind the epigram 'Never ascribe to malice that which is adequately explained by incompetence': surely a valuable thing to bear in mind during frustrating and dissatisfying encounters with government. Elder notes the recent introduction of a new licensing scheme that he hopes will smooth over the problems of the past few years. We hope he is correct, but anticipate further problems before the issue is better resolved.

Lapinoja and Sutphin provide valuable international perspectives on these questions. Lapinoja outlines the vague and largely unhelpful legal frameworks around archaeological human remains in Finland, and the related question of repatriation of remains to the indigenous Sámi community. Her conclusions are encouraging: despite differences of opinion between archaeologists and others, a number of mutually satisfactory compromises have been reached in the ethical treatment of human remains in Finland. Sutphin's response outlines the American manifestations of the human remains problem: a vast field that she summarises succinctly. Her discussion of the Native American Graves Protection and Repatriation Act (NAGPRA) and the problem of human remains and sacred objects refers to 'consultation with closely linked descendants or descendant groups'. Sutphin takes issue with our suggestion that the practice of science in the United States is hampered by religious interference. Despite the example that we 
provided (stem cell research, a well-attested example of religious opposition to scientific research in the US), she chooses to reply as if we were referring only to human remains, and as if our criticism were directed only at fundamentalist Christianity. This misrepresentation of our argument contributes little to the debate. A valuable aspect of Sutphin's paper is her evaluation of the impact of NAGPRA, which she argues has had positive impacts on human remains scholarship and has not been the disaster for archaeology that some had feared.
Despite the optimistic title of our initial article, we do not expect the human remains crisis or (more realistically) crises in British archaeology to be resolved quickly or to everyone's satisfaction. The fascination and powerful emotional responses that human remains can generate and the knowledge that they can provide will ensure that this remains a lively and productive field of discourse. Once again we would like to thank the discussants for their contributions to this forum, and to the editors of PIA for commissioning it. 